\title{
Customer retention in five-star hotels in Jordan: The mediating role of hotel perceived value
}

\author{
Owais Barkat Al-Gharaibah ${ }^{\mathbf{a}^{*}}$
}

a Taibah University, College of Business Administration, Marketing Department, Saudi Arabia

\begin{tabular}{l}
\hline C H R O N I C L E \\
\hline Article history: \\
Received: June 30, 2020 \\
Received in revised format: \\
June 302020 \\
Accepted: July 12, 2020 \\
Available online: \\
July 12, 2020 \\
\hline Keywords: \\
Customer Retention \\
Customer Satisfaction \\
Physical environment \\
Service Quality
\end{tabular}
A B S T R A C T

Customer retention (CR) has become increasingly important due to high competition among hotels and countries. However, most of previous studies focus on this variable in the context of restaurants. This study aims to examine the factors that affect the CR among customers of five-star hotels in Jordan. Based on the literature, the study proposes that physical environment (PE), customer satisfaction (CS), service quality (SQ), and perceived consumption value (PCV) will affect the CR. In addition, the study proposes that hotel perceived value (HPV) will mediate the effects between the variable. The population of this study is the hotels in Amman, the capital of Jordan. Using a random sampling technique, a total of 301 responses are collected from seven brands. The findings indicated that PE, SQ, PCV, and CS were important predictors of CR. The findings also show that HPV mediated partially the effect of PE and SQ on CR while a full mediator was found between CS and CR. Decision makers are advised to improve the PE and the HPV.

C 2020 by the authors; licensee Growing Science, Canada

\section{Introduction}

Hospitability has become increasingly important not only for hotels and service providers but also for the country and the economy. Several countries rely mainly on tourism as a source of foreign capital. For this reason, the competition among countries and hotels in the same countries is fierce (Nugroho, Kempa, \& Wiliater Soaloon Panjaitan, 2020). The dependency on tourism among countries varied between $70 \%$ as contribution to countries such as Maldives and $19.2 \%$ in countries such as Jordan (Knoema, 2018). In the process of hospitality, hotels are critical for the supply chain of tourism. Hotels are service oriented organizations and customers are the main sources of incomes. CR is critical for the survival of the hotels. Most of hotels are striving to retain customers due to the fact that the occupancy rate in most countries are low. For example, in Jordan, the Jordan Hotel Association (JHA, 2020) indicated that until December 2019, the occupancy rate is 33\% indicating that almost $63 \%$ of rooms are empty. Such situation increased the operational cost and reduced the contribution of tourism to the country. Further, it is widely established that retaining existing customers is five times cheaper than attracting a new one (Han, Shim, Lee, \& Kim, 2019). It is believed that the reasons for low occupancy rate is related to factors such as the low income of the citizens as Jordan is classified by the United Nation (UN) as upper middle-income nations. National and foreigners prefer 3 and 4 stars hotels due to the differences in price and perceived values. In addition, the PE as well as the SQ and CS play essential role in determining the customer intention to recommend and use the hotels again.

Against this background, previous studies did not focus on the CR in hotel industry and especially among five-star hotels. Previous studies were into services such as retailers (Cuong, 2020; Jiang, Luk, \& Cardinali, 2018; Kim \& Yun, 2019; Mukerjee, 2018), restaurants (Çetinsöz, 2019; Nugroho et al., 2020), or car renting (Simanjuntak, Putri, Yuliati, \& Sabri, 2020). Previous studies also were conducted in developed countries while studies that examined the CR in Jordan are limited (Hawkins \& Hoon, 2019). 
Several factors were proposed in previous studies to affect the CR. For instance, previous studies related the CR to the use of customer relationship management (CRM) (Simanjuntak et al., 2020), product performance (Han et al., 2019), perceived justice and loyalty (Bahri-Ammari \& Bilgihan, 2019), trust (Education \& Studies, 2020), promotion and pricing strategies (Kim, 2019). Few studies examined the effect of factors such as PE, CS, SQ as well as the PCV. In addition, few of the previous studies have deployed the HPV as a mediator in the context of five-star hotels.

Accordingly, this study aims to examine the CR in five-star hotels in Jordan. The study aims to identify the factors that affect the CR and the mediating effect of the HPV. The remaining of this paper discusses the literature review, research methodology, findings, implications, and conclusion.

\section{Literature Review and Hypotheses Development}

This section discusses the literature pertaining to CR as well as the factors that affect the CR. The section also discusses the development of hypotheses of this study.

\subsection{Customer Retention (CR)}

In service oriented industry such as hospitality, CR is the ultimate goal of all hotels (Mokhtaruddin, Wel, \& Khalid, 2019). There are several definitions of CR. For instance, CR was defined as "the way in which a company can keep its customers and maintain its customer portfolio" (Bahri-Ammari \& Bilgihan, 2019), other definition look into the CR as transferring the new customer to regular customers and keep good relationship with them (Mokhtaruddin et al., 2019). Thus, CR is to maintain the base of customers and turn them to loyal customers to the organization (Hawkins \& Hoon, 2019; Nugroho et al., 2020; Syaqirah \& Faizurrahman, 2014). Previous studies indicated that an increase by $1 \%$ in CR can increase the profit of companies by $5 \%$ (Hawkins \& Hoon, 2019). Nevertheless, previous studies dealing with CR focused on factors such as loyalty program and the use of CRM as well as the relationship marketing tools (Mokhtaruddin et al., 2019) while variables that are related to the context of the hotels and the quality of the service provided received less attention. In this study, the effect of factors such as the PE as well as the PCV, CS, and SQ are expected to have an effect on the retention of customers in five-star hotels in Jordan.

\subsection{Conceptual Model and Hypotheses Development}

Based on previous studies and existing models and frameworks, this study proposed that the PE, CS, SQ and PCV will have direct effects on the CR. The study also proposed that the HPV will mediate the effect of these variables on CR. Accordingly, Fig. 1 shows the conceptual framework of this study.

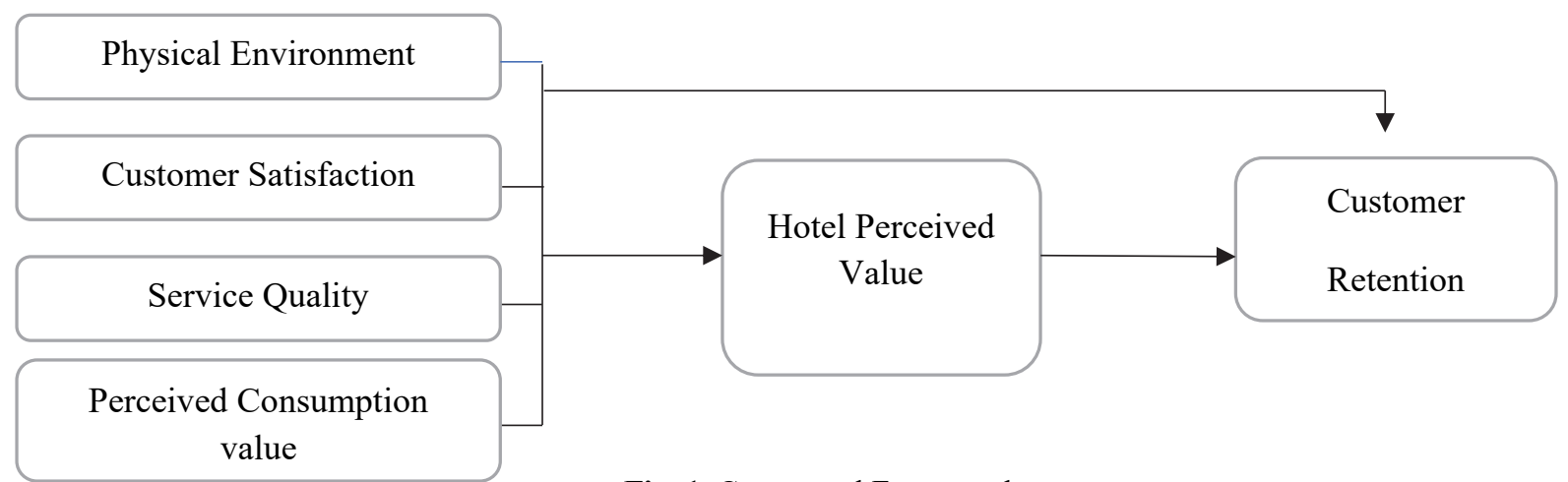

Fig. 1. Conceptual Framework

\subsubsection{The Relation between $P E$ and $C R$}

PE refers to the physical layout and design of the hotel and it includes the atmosphere, décor, and cleanness (Çetinsöz, 2019; Han, Jongsik, \& Hyun, 2020; Syaqirah \& Faizurrahman, 2014). PE is important predictors of the behavior of customers and can determine the loyalty of the customers to the organization (Cuong, 2020). Previous studies indicate that the attitude toward the SQ and the hotel is formed by the PE of the hotel (Hussein, Hapsari, \& Yulianti, 2018). Few of the previous studies examined the effect of PE on the CR in the context of hotels. For example, the PE such as décor and layout influenced the perception of customer toward price and the loyalty (Han \& Ryu, 2009). Similarly, a study by Samah, Rashid, Rani, Rahman and Ali (2015) found that PE affected positively the customer loyalty of restaurants. On the other hand, a study by Cuong (2020) derived empirical support for the relationship between PE and CS while failed to support the relationship between PE and behavioral intention. Nevertheless, the relationship between PE and behavioral intention of customers was supported in the study of (Calza, Pagliuca, Risitano, \& Sorrentino, 2020). Accordingly, in this study, it is proposed that the CR of five-star hotels in Jordan will be positively affected by the PE. Thus, it is hypothesized: 
$\mathrm{H}_{1}$ : PE affects positively the CR of five-star hotels in Jordan

\subsubsection{The Relation between $C S$ and $C R$}

CS is an essential concept in marketing because it is important to meet the demand of customers. It is defined as "service performance countering or exceeds customer expectations (Çetinsöz, 2019). Previous studies examined the effect of CS on variables such as loyalty but few examined its effect on CR of five-star hotels. For instance, in the study of El-Adly (2019) Keshavarz and Jamshidi (2018), a significant positive relationship was found between CS and customer loyalty. CS also affected the behavioral intention of customers (Cuong, 2020). Among the few studies that examined the relationship between CS and CR is the study of (Hawkins \& Hoon, 2019) and the study of (Simanjuntak et al., 2020) who found a significant effect of CS on CR. Thus, in this study, it is proposed that CS will affect the CR of five-star hotels in Jordan. Accordingly, the following is hypothesized:

$\mathrm{H}_{2}$ : CS affect positively the CR of five-star hotels in Jordan.

\subsubsection{The Relation between $S Q$ and $C R$}

SQ is important indicators of several marketing outcome such as CS, word of mouth and customer loyalty (Mukerjee, 2018). Hotels obtain competitive advantage over competitors by differentiating their services. It is proven in hotel industry that poor SQ will lead to a loss of an average 12\% of customers (Keshavarz \& Jamshidi, 2018). SQ has been used as a determinant of CS (Kazmi, 2020; Pradeep, Vadakepat, \& Rajasenan, 2020), customer loyalty (Keshavarz \& Jamshidi, 2018; Mokhtar, Mus, \& Sjahruddin, 2019). Few studies examined the relationship between SQ and CR. For instance, the study of Nugroho et al. (2020) found a significant relationship between SQ and CR. In this study, it is expected that SQ will have a significant effect on CR. Accordingly, it is hypothesized:

$\mathrm{H}_{3}$ : there is a significant positive effect of SQ on CR of five-star hotels in Jordan.

\subsubsection{The Relation between PCV and CR}

PCV is derived from the good and services and it is one of the main drivers for customer attitude and behavior. It is defined as the utility derived from the perceived quality and expected performance of the service at a given cost (Suracharkumtonkun \& Patterson, 2007). PCV has been intensively investigated in the context of food and restaurant while the impact of this variable on the CR in the context of hotel has received limited attention (Jiang et al., 2018; S. (Sam) Kim \& Choe, 2013). The effect of PCV was found significant on behavioral intention of customer in several studies (Hung \& Hsieh, 2010; Peng, Chen, \& Wen, 2014; Yoon, Seo, \& Yoon, 2015). In the tourism industry, the effect of PCV was found to be significant on customer loyalty (Shu Wan Tan, Falahat, \& Kai Sia, 2018). Previous studies also found that the effect of PCV on CS is significant (Wongsuchat \& Ngamyan, 2014). In this study, it is expected that the effect of PCV on the CR will be positive and significant. Accordingly, it is hypothesized:

$\mathrm{H}_{4}$ : PCV has a significant effect on CR of five-star hotels in Jordan.

\subsubsection{The mediating effect of the HPV}

The HPV is defined as customer overall evaluations based on the perception of what is given and what is received (Zeithaml, 1988). Perceived hotel value is critical for the hospitability industry and it is a predictor of the customer loyalty and CR (Hussein et al., 2018). Perceived hotel value is essential for CS, loyalty and purchase intention (Pham et al., 2020). Few of the previous studies examined the role of the perceived hotel value as a mediator. For example, perceived value mediated the effect of SQ on customer loyalty (Keshavarz \& Jamshidi, 2018). In the study of Hussein et al. (2018), the mediating role of perceived value was confirmed. Perceived value mediated the effect of PE on customer loyalty of hotels. Perceived value also mediated the effect of CS on customer loyalty (El-Adly, 2019).

Based on the above discussion, it is proposed in this study that perceived hotel value will mediate the effect of PE, CS, SQ, and PCV on CR of five-star hotels in Jordan. Accordingly, the following is hypothesized:

$\mathrm{H}_{5}$ : perceived hotel value mediates the effect of PE on CR.

$\mathrm{H}_{6}$ : perceived hotel value mediates the effect of $\mathrm{CS}$ on $\mathrm{CR}$.

$\mathrm{H}_{7}$ : perceived hotel value mediates the effect of SQ on CR.

$\mathrm{H}_{8}$ : perceived hotel value mediates the effect of PCV on CR.

\section{Research Methodology}

This study is a quantitative and aims to find the factors that affect the CR in five-star hotels in Jordan. The population of this study is customers of five-star hotels. There are 47 five-star hotels in Jordan. However, due to the fact that most of the hotels 
are in Amman, the capital of Jordan, this study focuses only on hotels in Amman. Hotels are operating under seven main brands. According to Jordan Times, there are 4.5 million tourists have visited Jordan in 2019. Out of which, 3\% were guests in five-star hotels. This makes the population of this study 135,000. The sample of this study is a random sampling. This is because all the visitors share similar characteristic. According to Sekaran and Bougie (2016), for a population of 135,000 with confidence rate of 0.95 and margin error of 0.05 , the sample size is 383 .

Data of this study was collected using a questionnaire. The questionnaire was adopted from previous sources. PE (17 items), HPV (5 items), and CS (7 items) were adopted from (Calza et al., 2020). SQ consists of 14 items and it was adopted from (Mukerjee, 2018). CR consists of 3 items and it was adopted from (Simanjuntak et al., 2020). PCV consists of 5 items and it was adopted from (Wongsuchat \& Ngamyan, 2014). Prior to field data collection, the questionnaire was validated by two experts. The comments and feedback of the experts was addressed accordingly. A pilot study was conducted to examine the reliability of the measurement and it was found that all measurements have Cronbach's Alpha greater than 0.70 indicating that the measurement is reliable (Sekaran \& Bougie, 2016).

Data was collected from seven brands. Each of the brand has a hotel operating in Amman. The management of the hotels were asked for help in collecting the data. An online questionnaire was created for the purpose of data collection. The first round of data collection resulted in 97 questionnaires. Further follow up and call resulted in additional 239 questionnaires. This made the total number of collected questionnaire account to 336 with response rate of $61.6 \%$. This number is sufficient for using Smart Partial Least Square (Smart PLS) (Alaaraj, Mohamed, \& Ahmad Bustamam, 2018; Alaarj, Abidin-Mohamed, \& Bustamam, 2016; Alaarj, Mohamed, \& Bustamam, 2017a, 2017b).

\section{Findings}

This section presents the data analysis and it includes the procedures of data examination, descriptive statistics, and hypotheses testing using Smart PLS.

\subsection{Data Examination}

Before proceeding with data analysis, the data must be refined and examined (Hair, Hult, Ringle, \& Sarstedt, 2017). Mainly, the preliminary analysis includes the missing value, outliers, normality, and multicellularity. The data had 16 missing values that exceed $15 \%$ of the answers. Accordingly, these responses were deleted. This makes the complete data account to 320 . The outliers showed that some of the responses are far from the mean score and accordingly a total of 19 responses were removed based on outliers' basis. This made the valid responses account to 301 . Further, the analysis of normality showed that the data is normally distributed with kurtosis and skewness less than 1 indicating that the data is normally distributed (Hair et al., 2017). Furthermore, the multicollinearity was conducted by examining the tolerance and the variation inflation factor (VIF). The value of tolerance greater than 0.20 while the value of VIF was less than 5 indicating that the data is free from the collinearity issue (Hair et al., 2017).

\subsection{Profile of Respondents}

A total of 301 respondents have participated in this study. The respondents are in their middle age with the mean around 43 years. The majority of the respondents are males $(71.8 \%)$ with bachelor's degree $(53.5 \%)$. Table 1 shows the profile of the respondents.

Table 1

Profile of respondents

\begin{tabular}{llcc}
\hline Variable & Label & Frequency & Percent \\
\hline Age & Less than 30 years & 8 & 2.7 \\
& 31-40 years & 96 & 31.9 \\
& 41-50 years & 154 & 51.2 \\
& 51-60 years & 35 & 11.6 \\
\hline \multirow{2}{*}{ Gender } & More than 60 years & 8 & 2.7 \\
& Male & 216 & 71.8 \\
\hline Education & Female & 85 & 28.2 \\
& Master's Degree & 140 & 46.5 \\
\hline
\end{tabular}

$\mathrm{N}: 301$

\subsection{Measurement Model}

Researchers such as Hair et al. (2017) pointed out that the measurement model can be assessed using the factor loading and the Cronbach's Alpha as well as the composite reliability and the average variance extracted (AVE). Value of factor loading 
exceeding 0.70 are considered acceptable and less than 0.70 should be removed. Several items from the variables were removed due to low factor loading. Overall, all the remaining items were greater than 0.70. The Cronbach's Alpha and Composite Reliability is shown in Table 2 and it is greater than 0.70 . Thus, the measurements are reliable. The average variance extracted for all the variables are larger than 0.50 indicating that more than $50 \%$ of the variance in the variables can be explained by the items. This also confirms that the convergent validity is achieved (Hair et al., 2017; Lowry \& Gaskin, 2014). Table 2 shows the results of the measurement model.

Table 2

Results of the Measurement Model

\begin{tabular}{lccc} 
& Cronbach's Alpha $>0.70$ & Composite Reliability $>0.7$ & Average Variance Extracted (AVE) $>0.50$ \\
CR & 0.808 & 0.886 & 0.722 \\
CS & 0.920 & 0.938 & 0.715 \\
HPV & 0.878 & 0.911 & 0.672 \\
PCV & 0.837 & 0.891 & 0.672 \\
PE & 0.929 & 0.940 & 0.612 \\
SQ & 0.912 & 0.932 & 0.696 \\
\hline
\end{tabular}

The discriminant validity is achieved if the root square of the AVE is greater than its row and column (Hair et al., 2017; Lowry \& Gaskin, 2014). In Table 3, the root square of AVE is presented in bold and it shows that the number are greater than the row and column. Therefore, the discriminant validity is achieved.

Table 3

Discriminant Validity

\begin{tabular}{lccccc}
\hline & CR & CS & HPV & PCV & \\
\hline CR & 0.850 & & & & \\
CS & 0.429 & 0.846 & 0.820 & 0.820 & \\
HPV & 0.637 & 0.400 & 0.425 & 0.510 & 0.782 \\
PCV & 0.536 & 0.320 & 0.479 & 0.536 & 0.520 \\
PE & 0.617 & 0.483 & 0.834 \\
SQ & 0.606 & & & \\
\hline
\end{tabular}

\subsection{Structural Model}

The structural model is assessed by the R-square, F-square, Q-square, and the path coefficient. In Table 4, the results of the structural model are shown. The number of the hypothesis $(H)$, the coefficient $(B)$, standard deviation (St.d), t-value (T), pvalue $(\mathrm{P}), \mathrm{R}$-square, $\mathrm{Q}$-square, and F-square are included in this table.

\section{Table 4}

Results of direct effect

\begin{tabular}{|c|c|c|c|c|c|c|c|c|}
\hline $\mathrm{H}$ & Path & $\mathrm{B}$ & St.d & $\mathrm{T}$ & $\mathrm{P}$ & R-square & Q-square & F-square \\
\hline $\mathrm{H} 1$ & $\mathrm{PE} \rightarrow \mathrm{CR}$ & 0.345 & 0.054 & 6.381 & 0.000 & 0.528 & 0.377 & 0.166 \\
\hline $\mathrm{H} 2$ & $\mathrm{CS} \rightarrow \mathrm{CR}$ & 0.132 & 0.056 & 2.367 & 0.018 & & & 0.028 \\
\hline $\mathrm{H} 3$ & $\mathrm{SQ} \rightarrow \mathrm{CR}$ & 0.272 & 0.063 & 4.317 & 0.000 & & & 0.087 \\
\hline $\mathrm{H} 4$ & $\mathrm{PCV} \rightarrow \mathrm{CR}$ & 0.174 & 0.051 & 3.403 & 0.001 & & & 0.041 \\
\hline
\end{tabular}

The r-square is 0.528 indicates that $52.8 \%$ of the variation in CR can be explained by the four variables. The predictive relevance (Q-square) was examined using the blindfolding. The Q-square as shown in Table 4 is greater than 0 indicating that the independent variables are able to predict the dependent variable. For the F-square, the rule of thumb that the value of Fsquare greater than 0.02 is acceptable. Table 4 shows the value of F-square is greater than 0.02 .

\subsection{Hypotheses Testing}

This study has developed eight hypotheses. Four of the hypotheses are direct while the other four are indirect. In the next sections, the results of the direct and indirect effects are presented.

\subsubsection{Direct Effect}

The results of the four direct effect hypotheses were presented in Table 4. It shows that the effect of PE on CR is significant $(\mathrm{B}=0.345, \mathrm{~T}=6.381, \mathrm{P}<0.001)$. Thus, $\mathrm{H} 1$ is supported. The effect of $\mathrm{CS}$ on $\mathrm{CR}$ is positive and significant $(\mathrm{B}=0.132, \mathrm{~T}=2.367$, $\mathrm{P}=0.018)$. Thus, $\mathrm{H} 2$ is supported. For the third hypothesis, it was found that $\mathrm{SQ}$ has a significant effect on $\mathrm{CR}(\mathrm{B}=0.272$, $\mathrm{T}=4.317, \mathrm{P}<0.001)$. Thus, $\mathrm{H} 3$ is supported. For the fourth hypothesis, the effect of PCV on CR is positive and significant $(\mathrm{B}=0.174, \mathrm{~T}=3.403, \mathrm{P}=0.041)$. Thus, $\mathrm{H} 4$ is supported. 
The results of the mediation effect of HPV is presented in Table 5. The mediator is tested by comparing the direct and indirect effect (Hair et al., 2017). If the direct effect after entering the mediator reduced and turned insignificant, then a full mediator is assumed. However, if the direct effect reduced and stayed significant, then a partial mediator is assumed. No mediation is assumed when the indirect effect is insignificant. Fig. 2 shows the results of testing the mediating effect of HPV.

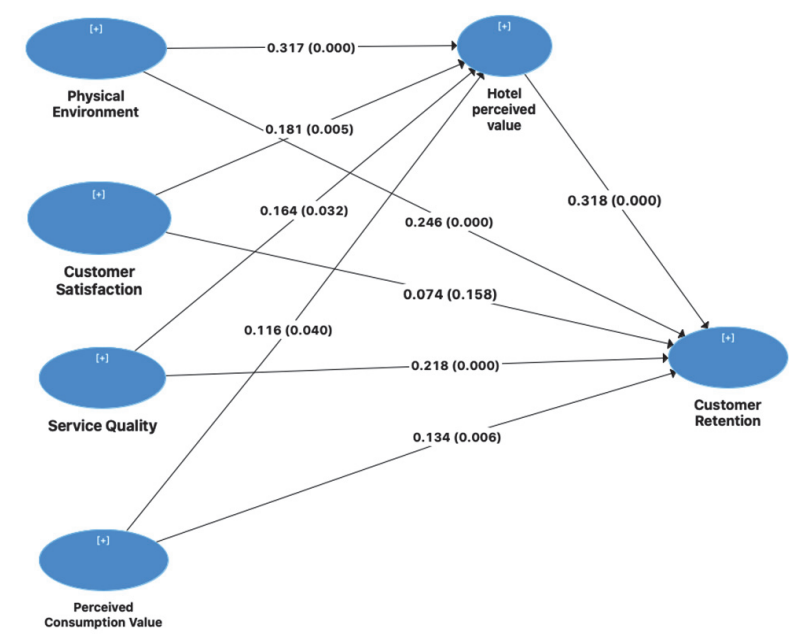

Fig. 2. Results of Mediation Testing

In Table 5, it can be seen that the HPV mediated partial the effect of PE and SQ on CR. Thus, H1 and H3 are partially accepted. A full mediator was found between CS and CR. Thus, H2 is supported. For the mediating effect of perceived hotel value between PCV and CR, it was rejected because the indirect effect is not significant.

Table 5

Mediating Effect of Hotel Perceived Value

\begin{tabular}{|c|c|c|c|c|c|c|}
\hline $\mathrm{H}$ & Path & $\mathrm{B}$ & St.d & $\mathrm{T}$ & $\mathrm{P}$ & Remark \\
\hline & $\mathrm{CS} \rightarrow \mathrm{CR}$ & 0.074 & 0.052 & 1.412 & 0.158 & Rejected \\
\hline & $\mathrm{CS} \rightarrow \mathrm{HPV}$ & 0.181 & 0.065 & 2.805 & 0.005 & Accepted \\
\hline & $\mathrm{HPV} \rightarrow \mathrm{CR}$ & 0.318 & 0.056 & 5.723 & 0.000 & Accepted \\
\hline & $\mathrm{PCV} \rightarrow \mathrm{C}$ & 0.134 & 0.049 & 2.765 & 0.006 & Accepted \\
\hline & $\mathrm{PCV} \rightarrow \mathrm{HPV}$ & 0.116 & 0.056 & 2.058 & 0.040 & Accepted \\
\hline & $\mathrm{PE} \rightarrow \mathrm{CR}$ & 0.246 & 0.052 & 4.729 & 0.000 & Accepted \\
\hline & $\mathrm{PE} \rightarrow \mathrm{HPV}$ & 0.317 & 0.070 & 4.566 & 0.000 & Accepted \\
\hline & $\mathrm{SQ} \rightarrow \mathrm{CR}$ & 0.218 & 0.062 & 3.541 & 0.000 & Accepted \\
\hline & $\mathrm{SQ} \rightarrow \mathrm{HPV}$ & 0.164 & 0.077 & 2.139 & 0.032 & Accepted \\
\hline H5 & $\mathrm{PE} \rightarrow \mathrm{HPV} \rightarrow \mathrm{CR}$ & 0.101 & 0.028 & 3.643 & 0.000 & Accepted \\
\hline H6 & $\mathrm{CS} \rightarrow \mathrm{HPV} \rightarrow \mathrm{CR}$ & 0.058 & 0.022 & 2.561 & 0.010 & Accepted \\
\hline $\mathrm{H} 7$ & $\mathrm{SQ} \rightarrow \mathrm{HPV} \rightarrow \mathrm{CR}$ & 0.052 & 0.027 & 1.973 & 0.048 & Accepted \\
\hline $\mathrm{H} 8$ & $\mathrm{PCV} \rightarrow \mathrm{HPV} \rightarrow \mathrm{CR}$ & 0.037 & 0.020 & 1.873 & 0.061 & Rejected \\
\hline
\end{tabular}

\section{Implications}

This study has contributed to the literature and the practices of increasing the CR among customers of five-star hotels in Jordan. The study investigated the CR among customers of five-star hotels in developing countries such as Jordan while previous studies focused on customer loyalty and its predictors in developed nations or in other sectors such as the restaurant industry. The study also contributed to the literature by examining the mediating role of HPV while previous studies did not pay much attention on this variable. In practice, the study has identified the predictors of CR and based on the findings, decision makers in hospitability industry are advised to enhance the PE because it is the most important predictor of CR. Open air area as well as swimming pool and unique design can be a contributing factors to improve the PE. In addition, decision makers are advised to enhance the SQ because it is important to drive the CR. PCV and CS are important predictors of CR.

The above findings and suggestions are in agreement with previous studies (Çetinsöz, 2019; El-Adly, 2019; Han et al., 2020; Hussein et al., 2018; Keshavarz \& Jamshidi, 2018; Mokhtar et al., 2019; Syaqirah \& Faizurrahman, 2014). The study also found that perceived hotel value can explain part of the relationship between SQ and PE with CR while can explain fully the relationship between CS and CR. Accordingly, decision makers are advised to increase the perceived hotel values to customer 
to increase their retention. This finding is in line with the findings of previous studies (El-Adly, 2019; Hussein et al., 2018; Keshavarz \& Jamshidi, 2018; Pham et al., 2020)

\section{Conclusion and recommendations and further research}

This study was conducted to understand the predictors of CR in five-star hotels in Jordan. Seven brands were selected and data was collected from 301 customers. The findings have indicated that PE, SQ, PCV, and CS in order of importance were the most important predictors of CR. Further, the mediating role of HPV was examined and the result indicated that the HPV mediated partially the effect of PE and SQ on CR. A full mediator was found between CS and CR. No mediation was found between PCV and CR. There are several limitations that can be a direction for future work. This study collected data from 301 customers in seven brand hotels in Amman, the capital of Jordan. Future studies are recommended to expand the sample size to include other major touristic attractions in Jordan such as the dead sea and Petra. The study has included four variables as predictors, future studies are recommended to include more predictors such as trust in the hotel. Future studies also are advised to investigate the moderating role of nationality and income or profession. The study was conducted in Jordan, future studies are recommended to replicate this study in other countries such as in the middle east and gulf countries.

\section{References}

Alaaraj, S., Mohamed, Z. A., \& Ahmad Bustamam, U. S. (2018). External growth strategies and organizational performance in emerging markets: The mediating role of inter-organizational trust. Review of International Business and Strategy, 28(2), 206-222. https://doi.org/10.1108/RIBS-09-2017-0079

Alaarj, S., Abidin-Mohamed, Z., \& Bustamam, U. S. B. A. (2016). Mediating role of trust on the effects of knowledge management capabilities on organizational performance. Procedia - Social and Behavioral Sciences, 235, $729-738$.

Alaarj, S., Mohamed, Z. A., \& Bustamam, U. S. A. (2017a). Do knowledge management capabilities reduce the negative effect of environment uncertainties on organizational performance? A study of public listed companies in Malaysia. International Journal of Economic Research, 14(15), 443-456.

Alaarj, S., Mohamed, Z. A., \& Bustamam, U. S. A. (2017b). The effect of knowledge management capabilities on performance of companies : A study of service sector. International Journal of Economic Research, 14(15), 457-470.

Bahri-Ammari, N., \& Bilgihan, A. (2019). Customer retention to mobile telecommunication service providers: the roles of perceived justice and customer loyalty program. International Journal of Mobile Communications, 17(1), 82-107.

Calza, F., Pagliuca, M., Risitano, M., \& Sorrentino, A. (2020). Testing moderating effects on the relationships among onboard cruise environment, satisfaction, perceived value and behavioral intentions. International Journal of Contemporary Hospitality Management, 32(2), 934-952. https://doi.org/10.1108/IJCHM-09-2019-0773

Çetinsöz, B. C. (2019). Influence of physical environment on customer satisfaction and loyalty in upscale restaurants. Journal of Tourism and Gastronomy Studies, 7(2), 700-716.

Cuong, D. T. (2020). The effect of physical environment and perceived value on customer satisfaction and behavioral intention at the cinema in Vietnam. Test Engineering and Management, 82(1-2), 1665-1674.

Education, F. O. F., \& Studies, B. (2020). Customer Retention Through Trust in The Sharing Economy : Master Thesis, 20192020.

El-Adly, M. I. (2019). Modelling the relationship between hotel perceived value, customer satisfaction, and customer loyalty. Journal of Retailing and Consumer Services, 50, 322-332.

Hair, Hult, T. M., Ringle, C. M., \& Sarstedt, M. (2017). A primer on partial least squares structural equation modeling (2nd ed.). Thousand Oakes.

Han, H., Jongsik, Y., \& Hyun, S. S. (2020). Nature based solutions and customer retention strategy: Eliciting customer wellbeing experiences and self-rated mental health. International Journal of Hospitality Management, 86(December 2019).

Han, H., \& Ryu, K. (2009). The roles of the physical environment, price perception, and customer satisfaction in determining customer loyalty in the restaurant industry. Journal of Hospitality and Tourism Research. https://doi.org/10.1177/1096348009344212

Han, H., Shim, C., Lee, W. S., \& Kim, W. (2019). Product performance and its role in airline image generation and customer retention processes: gender difference. Journal of Travel and Tourism Marketing, 36(4), 536-548.

Hawkins, L., \& Hoon, S. (2019). The Impact of Customer Retention Strategies and the Survival of Small Service-Based Businesses. SSRN Electronic Journal, 5(564), 1-19. https://doi.org/10.4324/9781315853178

Hung, C. L., \& Hsieh, C. Y. (2010). Searching the fit pattern between cultural dimensions and consumption values of mobile commerce in Taiwan. Asia Pacific Management Review, 15(2), 147-165. https://doi.org/10.6126/APMR.2010.15.2.01

Hussein, A. S., Hapsari, R. D. V., \& Yulianti, I. (2018). Experience quality and hotel boutique customer loyalty: Mediating role of hotel image and perceived value. Journal of Quality Assurance in Hospitality and Tourism, 19(4), $442-459$.

JHA. (2020). Occupancy. Amman. Retrieved from http://johotels.org/statistics.aspx

Jiang, K., Luk, S. T. kwong, \& Cardinali, S. (2018). The role of pre-consumption experience in perceived value of retailer brands: Consumers' experience from emerging markets. Journal of Business Research, 86(September), 374-385.

Kazmi, M. (2020). Measuring Service Quality' s Impact on Customer Satisfaction in the Hotel Enterprises of Islamabad: Assistance with Five Dimensions Artech Journal of Current Business and Financial Affairs ( AJCBFA ) Measuring Service Quality's Impact on Customer Sati, (February). 
Keshavarz, Y., \& Jamshidi, D. (2018). Service quality evaluation and the mediating role of perceived value and customer satisfaction in customer loyalty. International Journal of Tourism Cities, 4(2), 220-244.

Kim, J. (2019). The impact of different price promotions on customer retention. Journal of Retailing and Consumer Services, 46(September), 95-102. https://doi.org/10.1016/j.jretconser.2017.10.007

Kim, S. (Sam), \& Choe, J. Y. (Jacey). (2013). Testing an attribute-benefit-value-intention (ABVI) model of local food consumption as perceived by foreign tourists. International Journal of Contemporary Hospitality Management, 31(1), 123-140.

Kim, T., \& Yun, S. (2019). How will changes toward pro-environmental behavior play in customers' perceived value of environmental concerns at coffee shops? Sustainability (Switzerland), 11(14). https://doi.org/10.3390/su11143816

Knoema. (2018). Contribution of travel and tourism to GDP as a share of GDP. Retrieved from https://knoema.com/atlas/topics/Tourism/Travel-and-Tourism-Total-Contribution-to-GDP/Contribution-of-travel-andtourism-to-GDP-percent-of-GDP

Lowry, P. B., \& Gaskin, J. (2014). Partial least squares (PLS) structural equation modeling (SEM) for building and testing behavioral causal theory: When to choose it and how to use it. IEEE Transactions on Professional Communication, 57(2), $123-146$.

Mokhtar, S., Mus, A. M., \& Sjahruddin, H. (2019). An examination of the relationships between customer relationship management quality, service quality, customer satisfaction and customer loyalty: The case of five star hotels. Advances in Social Sciences Research Journal, 6(2), 524-540.

Mokhtaruddin, S., Wel, C., \& Khalid, N. (2019). Employee Rhetorical Sensitivity As a Mediator in the Relationship Between Customer Orientation and Customer Retention. The South East Asian Journal of Management, 13(2), 170-182.

Mukerjee, K. (2018). The impact of brand experience, service quality and perceived value on word of mouth of retail bank customers: Investigating the mediating effect of loyalty. Journal of Financial Services Marketing, 23(1), 12-24.

Nugroho, S., Kempa, S., \& Wiliater Soaloon Panjaitan, T. (2020). Logistic Service Quality and Customer Satisfaction to Customer Retention on Rice Producer Industry. SHS Web of Conferences, 76, 01048. https://doi.org/10.1051/shsconf/20207601048

Peng, K. F., Chen, Y., \& Wen, K. W. (2014). Brand relationship, consumption values and branded app adoption. Industrial Management and Data Systems, 114(8), 1131-1143.

Pham, N., Coomer, T., Lane, P., Limbu, Y. B., Williamson, S., \& Pham, L. (2020). Technology readiness and purchase intention: Role of perceived value and online satisfaction in the context of luxury hotels. International Journal of Management and Decision Making, 19(1), 1.

Pradeep, S., Vadakepat, V., \& Rajasenan, D. (2020). The effect of service quality on customer satisfaction in fitness firms. Management Science Letters, 10(9), 2011-2020. https://doi.org/10.5267/j.msl.2020.2.011

Samah, I. H. A., Rashid, I. M. A., Rani, M. J. A., Rahman, N. I. A., \& Ali, M. F. S. (2015). The roles of price perception and physical environment in determining customer loyalty: Evidences from fast food restaurant of Malaysia. International Journal of Development Research.

Sekaran, U., \& Bougie, R. (2016). Research methods for business: A skill building approach. John Wiley \& Sons.

Shu Wan Tan, A., Falahat, M., \& Kai Sia, B. (2018). Perceived consumption values, satisfaction and loyalty in the Tourism: Case of Malaysia. International Journal of Engineering \& Technology, 7(3.21), 368.

Simanjuntak, M., Putri, N. E., Yuliati, L. N., \& Sabri, M. F. (2020). Enhancing customer retention using customer relationship management approach in car loan bussiness. Cogent Business and Management, 7(1).

Suracharkumtonkun, J., \& Patterson, P. (2007). The Role of Social Capital and On-Line Communities in Enhancing Consumers' Consumptionn Value. Australian and New Zealand Marketing Academy (ANZMAC) Conference, (March 2015), 2938-2945. Retrieved from http://smib.vuw.ac.nz:8081/WWW/ANZMAC2007/papers/J Surachartkumtonkun 1a.pdf

Syaqirah, Z. N., \& Faizurrahman, Z. P. (2014). Managing Customer Retention of Hotel Industry in Malaysia. Procedia Social and Behavioral Sciences, 130, 379-389. https://doi.org/10.1016/j.sbspro.2014.04.045

Wongsuchat, P., \& Ngamyan, A. (2014). A study of relation among perceived consumption value and customer satisfaction of boutique hotel in Thailand. International Journal of Scientific and Research Publications, 4(7), 2250-3153.

Yoon, S.-W., Seo, M.-O., \& Yoon, D.-I. (2015). The Effects of Perceived Consumption Value on Brand Identification, Emotional Commitment and Behavioral Commitment. Journal of the Korea Academia-Industrial Cooperation Society, 16(9), 5989-5997. https://doi.org/10.5762/kais.2015.16.9.5989

Zeithaml, V. A. (1988). Consumer Perceptions of Price, Quality, and Value: A Means-End Model and Synthesis of Evidence. Journal of Marketing. https://doi.org/10.2307/1251446

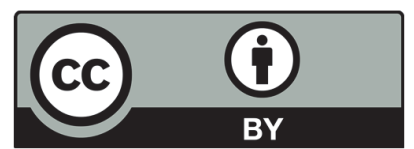

(C) 2020 by the authors; licensee Growing Science, Canada. This is an open access article distributed under the terms and conditions of the Creative Commons Attribution (CC-BY) license (http://creativecommons.org/licenses/by/4.0/). 